\title{
Beyond issue diversification: N-VA and the communitarisation of political, economic and cultural conflicts in Belgium
}

\author{
Koen Abts, Emmanuel Dalle Mulle \& Rudi Laermans
}

To cite this article: Koen Abts, Emmanuel Dalle Mulle \& Rudi Laermans (2019): Beyond issue diversification: N-VA and the communitarisation of political, economic and cultural conflicts in Belgium, West European Politics, DOI: 10.1080/01402382.2019.1576407

To link to this article: https://doi.org/10.1080/01402382.2019.1576407

曲 Published online: 08 Mar 2019.

Submit your article to this journal $\widetilde{ }$

Џ Article views: 38

View Crossmark data $\complement$ 


\title{
Beyond issue diversification: N-VA and the communitarisation of political, economic and cultural conflicts in Belgium
}

\author{
Koen Abts $^{a}$ (D), Emmanuel Dalle Mulle ${ }^{b}$ (D) and Rudi Laermans ${ }^{c}$ \\ ${ }^{a}$ Department of Sociology, Tilburg University, Tilburg, The Netherlands; ${ }^{b}$ International \\ History Department Graduate Institute of International and Development Studies, \\ Geneva, Switzerland; 'Centre for Sociological Research University of Leuven, \\ Leuven, Belgium
}

\begin{abstract}
Since the early 2000s, the Flemish nationalist party New Flemish Alliance (NVA) has experienced a burgeoning growth. Paradoxically, for a stateless nationalist and regionalist party (SNRP), this performance has occurred without major changes in mass support for independence and only ambiguous ones for more regional autonomy, which suggests that the party appeals to different electoral subgroups through a vote-maximisation strategy of issue diversification. Providing an in-depth analysis of the multi-dimensional ideology of N-VA, this article contributes to the literature on SNRPs by arguing that N-VA has gone beyond issue diversification through a strategy of 'issue communitarisation' that consists not only in expanding its agenda beyond the centre-periphery cleavage, but rather in framing all other policy issues explicitly in (sub-state) nationalist terms. According to this strategy, all major conflicts on political power, social redistribution and cultural identity are systematically represented as being based on an unresolvable and overarching centre-periphery antagonism between Flanders and francophone Belgium.
\end{abstract}

KEYWORDS Nationalism; ideology; welfare deservingness; N-VA; Flanders; Belgium

In 2001, after 47 years in Parliament and decades of gradual decline, the traditional ethno-regionalist party Volksunie (People's Union, VU) dissolved, torn apart by two opposing factions (Noppe and Wauters 2002). After an intra-party referendum, the most radical and largest faction, Vlaams-Nationaal (Flemish National), founded the Nieuw-Vlaamse Alliantie (New-Flemish Alliance, N-VA). This right-wing successor of the $\mathrm{VU}$ advocates a radicalisation of Flemish nationalism and opts for the establishment of an independent Republic of Flanders (Deschouwer 2009; Wauters 2005). Although Belgian regionalist parties have often been 
described as 'victims of their own success' (Van Haute and Pilet 2006), NVA has experienced an unexpected electoral revival. After a tottering start, overcome through an electoral alliance with the Flemish Christian Democrats $(\mathrm{CD} \& \mathrm{~V})$ in the period 2004-2008, N-VA has registered an impressive electoral growth from $4.8 \%$ of the Flemish vote in 2003 to $31.9 \%$ at the 2014 elections, becoming the largest party in Belgium and entering into a coalition government at both the regional and federal level.

Yet public opinion research suggests an interesting paradox: although there exists in Flanders a sizeable constituency in favour of more regional autonomy, N-VA's recent ascendancy has not been accompanied by major increases in popular support for Flemish independence and only ambiguous ones for more autonomy (Swyngedouw et al. 2015). In particular, N-VA has been able to appeal beyond the constituency of hardcore Flemish nationalists - only $17 \%$ of its voters are separatists - and to attract liberal-conservative electors of the Flemish centre-right parties, $\mathrm{CD} \& \mathrm{~V}$ and Open Vld, who are sceptical of multicultural society and the political establishment, as well as concerned about taxes and public spending. The party has also stolen voters from the populist radical right Vlaams Belang (VB), characterised by more outspoken anti-immigrant, authoritarian and politically cynical attitudes (Abts and Swyngedouw 2014). N-VA has thus successfully constructed an electoral coalition consisting of committed Flemish nationalist, liberal-conservative and traditional-authoritarian voters. Although N-VA has been able to attract a varied spectrum of electoral subgroups, a comprehensive analysis of the party's multi-dimensional nationalist discourse and its potential attractiveness to different sub-electorates is still lacking.

In line with the electoral tactics adopted in recent decades by other European stateless nationalist and regionalist parties (SNRPs), a strategy of issue diversification - whereby the party expands its policy portfolio beyond the centre-periphery cleavage (Alonso 2012) - can explain how $\mathrm{N}$-VA managed to broaden its appeal beyond hard-core nationalist voters. Yet comparative studies on issue diversification tend to take such expansion at face value, without inquiring into how diversification is concretely implemented. Our analysis of N-VA shows that the electoral appeal of NVA depends not only on issue diversification - meant as going beyond the centre-periphery cleavage - but also on a discursive strategy of 'issue communitarisation', which consists in casting the centre-periphery frame over other policy areas, using it as a prism to interpret redistribution, power and identity conflicts explicitly in (sub-state) nationalist terms.

The article is structured as follows: the next section discusses the existing literature on N-VA, along with that on SNRPs in general, and explains the method used. The following section provides an in-depth 
review of the ideological labels commonly attributed to N-VA. Inspired by the threefold distinction adopted by Bell (1973) and Habermas (1984) in their analyses of contemporary society, there follows a section focusing on the political, economic and cultural dimensions in N-VA's discourse. This allows us to unpack N-VA's frames and evaluate whether its rhetoric coincides with the mentioned ideological labels or not. In order to capture the party framing, we additionally introduce some new concepts, notably 'issue communitarisation' and 'welfare producerism'. The next section presents an explanatory framework that synthesises how N-VA's discourse re-articulates the Belgian political space in terms of particular homological and antagonistic relations. The article concludes with some considerations on the predominant articulation, through the nationalist frame, of the detected conservative, neoliberal and populist frames and how this articulation succeeds in systematically communitarising existing political, socio-economic and cultural conflicts within Belgian society. In this way, the article contributes to the literature on SNRPs and, notably, on how they adopt issue diversification as a vote maximisation strategy to compete with state-wide parties that adapt to regional devolution. More particularly, we provide an in-depth analysis of 'issue communitarisation' and of how this discursive tactic can help them successfully diversify their ideological profile (thus attracting a wider electorate), without losing their centre-periphery core electors.

\section{Literature and method}

Until now, most research dealing with N-VA has focused on a particular ideological framework (Ceuppens 2011; Pauwels 2011; Rochtus 2012), or described its discursive position(s) in terms of newness (Beyens et al. 2017) or party family, e.g. its closeness to ethno-regionalist parties (Dandoy 2010). Although Ico Maly (2012) has provided a thorough analysis of N-VA's ideology, his focus on the Enlightenment/AntiEnlightenment dichotomy is at times too wide (too general) and too narrow (it does not deal with a wide range of policy areas). We thus aim to go one step further by relating the party's discourse to the ideological labels (nationalism, populism, neoliberalism and conservatism) commonly attributed to N-VA and by arguing that not only issue diversification, but essentially 'issue communitarisation' is the underlying discursive strategy that has allowed the party to frame a diversity of issues, and to mobilise very different sub-electorates without betraying its nationalist core constituency.

Sonia Alonso (2012) has highlighted issue diversification as one of the most effective strategies used by SNRPs to adapt to the establishment of regional parliaments. She argues that the traditional literature on SNRPs 
wrongly considered them as single-issue parties, only mobilising along the centre-periphery cleavage. On the contrary, she proposes that SNRPs are actors capable of reacting to changes in their political environment, notably to the adoption on the part of state-wide parties of regionalist accommodative strategies as a consequence of devolution of powers to regional assemblies. In other words, in order to cope with competition from state-wide parties accepting (and even supporting) regional devolution, and to avoid becoming 'irrelevant', SNRPs clarify their ideological profile along the left-right continuum and/or introduce new policy issues within the political arena (e.g. immigration or environmental concerns) to fight off competition from state-wide parties. This is what she refers to as 'issue diversification'.

Yet Alonso's quantitative analysis, based on Manifesto-project data, gives no insight into SNRPs' discursive strategies to implement issue diversification. Other authors do describe the successful policy diversification strategies of some SNRPs. For example, Mitchell (1988) and Lynch (2002: 14) emphasise how, from the end of the 1980s, the Scottish National Party was able to move beyond a 'neither right, nor left' position into a clearer social-democratic outlook. ${ }^{1}$ Similarly, Culla i Clara (2013: 475-88) has shown how Esquerra Republicana de Catalunya (Republican Left of Catalonia, ERC) equally managed to profile itself as a reliable and competent left-wing party (see also Elias and Filippo 2011). In a comparative perspective, Dalle Mulle (2016; 2018: 186-204) and Dalle Mulle and Serrano (2018) have pointed out how SNRPs in Catalonia, Flanders and Scotland have tended to diversify their policy portfolio, as well as to make more pragmatic and instrumental arguments about self-determination. Yet none of these studies has put the construction of the multi-dimensional discourse required to implement an issue diversification strategy at the core of their analysis of SNRPs.

An in-depth qualitative content analysis is important to understand not only how SNRPs can concretely diversify their ideological profile, but also how these parties manage to cope with a major dilemma caused by issue diversification, i.e. that expanding beyond the pro-periphery electorate to attract more centrist voters risks triggering a backlash among the pro-periphery core constituency. In other words, 'the more the party wins at the centre the more it loses at the extreme' (Alonso 2012: 221). Our analysis of N-VA's discourse shows that the party has effectively been able to draw on multiple ideological references and to deal with various issues, but it has at the same time used the nationalist master frame as a glue holding together these various other frames through a strategy of 'issue communitarisation', whereby references to populism, neoliberalism, conservatism, and related political, economic and cultural issues, become 
grounded in an overarching centre/periphery conflict - in the Belgian context articulated in terms of a permanent antagonism between Flanders and Wallonia/francophone Belgium.

Before moving on, we need to explain how we conducted our qualitative content analysis. This is based on the following primary sources: manifestos for every regional and federal election between 2003 and 2014; all the issues of the monthly party publications Volle Manen (VM) (2001-2005) and Nieuw-Vlaams Magazine (N-VM) (2006-2014); articles published on the party's website; and some thematic brochures. The main rationale for choosing these public documents is that they are key channels through which the party conveys its ideological discourse to a wide audience. Additionally, our analysis includes a collection of interviews, speeches and opinion statements from leading party representatives that help further clarify N-VA's main tenets. The period of analysis goes from the party's foundation in 2001 to October 2014, when N-VA entered a federal government coalition. ${ }^{2}$ Following the methodological approach proposed by Mudde (2000: 18-24), our qualitative content analysis identifies the relevant ideological frames in N-VA's public discourse and explores the relation between the main arguments made by the party, as well as their hierarchical structuring. By subsequently relating N-VA's understanding of the social world to more abstract academic concepts, a somewhat flexible framework emerges that suits the study of party ideology, defined as a party's conceptual map of the social world (Freeden 1996: 76-7; Sainsbury 1980: 8). In this approach, we are interested in the in-depth structure of the party's socio-political view as well as its position on recurrent themes, rather than in conjectural and transient discourse.

\section{N-VA's political discourse: between nationalism, populism, neoliberalism and conservatism}

The starting point of our inquiry is a thorough discussion of the ideological labels usually attributed to N-VA. Only in this way can we properly assess the party's multi-dimensional discourse, its articulation and how the N-VA has diversified and eventually communitarised its rhetoric.

$\mathrm{N}-\mathrm{VA}$ has been predominantly described as a nationalist, populist, neoliberal and/or conservative party. Although these labels might seem to contradict each other, we should take into account that, as a rule, a political discourse is not a matter of stringent logic: it first and foremost involves the articulation - also in the sense of coupling - of various, even heterogeneous, principles into one discourse that precisely acquires a performative unity through the repeated association of seemingly colliding or even mutually contradictory notions or precepts (Hall 1986, 1988: 123-49; 
Laclau and Mouffe 1986; Zizek 1994). N-VA's discourse seems to be no exception. Nevertheless, given the often vague and multiple ways in which the mentioned labels are used, we start with a brief conceptual tour d'horizon to elucidate how we will deploy these categories.

First, virtually all authors consider N-VA a nationalist party. Nationalism is a thin-centred ideology (Freeden 1998) that asserts the existence of a cultural community of (formally) equal members endowed with political sovereignty (Greenfeld 1992: 3; see also Anderson 1983: 6). Accordingly, the nation - as a human population sharing its own culture, history and destiny - is the main source of legitimate political power and social solidarity, as well as the focus of citizens' loyalty (Smith 1999: 102). Hence, the nation state is the most legitimate form of state (Gellner 1983: 1). Tending to essentialism, nationalism often presents the nation as a homogenous unit with unique characteristics by defining clear boundaries between members and non-members, which eventually goes together with a negative stereotyping of relevant Others (Brubaker 2004: 74; Calhoun 1997: 44; Triandafyllidou 1998).

Second, N-VA has also been frequently called a populist party (Ceuppens 2011; Pauwels 2011). Populism is also a thin-centred ideology that advocates the sovereign rule of the people as a homogeneous body opposed to the corrupt political establishment ignoring the general will of the people (Abts and Rummens 2007: 407-9; Canovan 2002: 34; Mény and Surel 2002: 9; Mudde 2004: 543). This logic partly converts horizontal cleavages and conflicts within the people ('good') into a vertical, strongly moralised opposition against the alienated political establishment ('bad') (Abts and Rummens 2007: 418; Mudde and Rovira Kaltwasser 2017: 1-20; Stavrakakis 2004: 257). Furthermore, populism claims to present, not to represent, in a transparent way the will of the people and sets the people against Others who are threatening the people's rights, values, interest and identity (Albertazzi and McDonnell 2008: 3). Populism may thus generate a double vertical structure: upwards, the people are pitted against the elite; downwards, the people are antagonistically positioned towards a social Other, e.g. migrants and/or Islam (Abts and Laermans 2018).

Though populism and nationalism share some common ground, this double verticality signals a major difference between both ideologies. Indeed, whereas nationalism is mostly about boundary construction towards external Others, populism focuses on the internal vertical conflict between 'the true people' and the establishment and/or the social Other inhabiting the nation.

Third, Maly and Zienkowski (2011: 67) have defined N-VA as a neoliberal and conservative party because it wants to reduce state control over the economy and makes consistent reference to conservative 
thinking. In line with the analyses of Foucault (2008) and Harvey (2005), we regard the combined emphasis on entrepreneurship, competiveness and the efficiency of self-regulated markets as neoliberalism's key characteristics (see also Larner 2000; Peck and Tickell 2002; Hall and Lamont 2013). This entails a positive stance toward labour market flexibility, international free trade and capital mobility as well as an outspoken rejection of Keynesian demand management and a strong welfare state. In addition, we follow Oakeshott (1991) and Huntington (1957) in defining conservatism as characterised by the following core ideas: religion is the foundation of civil society; society is the product of slow historical growth; community prevails over the individual; rights stem from duties; individual responsibility is a key value; and the status quo or, alternatively, prudent evolution is favoured over change (Müller 2006). On the face of it, conservatism and neoliberalism are somewhat strange ideological bedfellows (Brown 2006). Whereas neoliberalism praises the enterprising individual and interpersonal competition, conservatism is a groupcentred view. Yet conservatism also stresses personal duties and responsibilities. Moreover, both discourses reject state intervention in general, and a strong welfare state in particular, because it corrodes individual engagement and accountability.

\section{Flanders-as-potential vs. the Belgian status quo}

Although the aforementioned labels generally fit N-VA's discourse, a nuanced account requires some additional concepts. The first notion is that of welfare producerism, i.e. a conditional concept of solidarity based on the deservingness criteria of control, attitude and reciprocity (see below). ${ }^{3}$ The second concept is that of communitarisation, or the systematic construction within the fields of economy, politics and culture of an unresolvable antagonism between the Flemish and the Walloon/francophone community. ${ }^{4}$ In N-VA's discourse, communitarisation allows nationalism to operate as an overarching frame subsuming political, socio-economic and cultural tensions or conflicts within Belgian society. The operation in effect rests on the playing off of a presumably existing state of affairs against a possible one within the domains of politics, the economy and culture.

\section{Political potential: responsible governance and the logic of two democracies}

N-VA's nationalism is not nostalgically backward looking but rather focuses on political and economic arguments, as well as on a future-oriented message of hope and change (Dalle Mulle 2016: 217-20; Rochtus 
2012: 278). Indeed, N-VA affirms in its foundational text that self-determination is 'not a goal, but a means to get better governance and more democracy' (VM 2001a). This communitarian logic, which was already affirmed in the first party manifesto (2001), but has been scaled up in intensity from 2009/10 onwards, associates Flanders with effective and efficient governance based on a culture of responsibility as opposed to a wasteful Wallonia addicted to financial interregional transfers (De Wever in Knack 2010). Claiming that Flanders represents the values of responsibility, hard work, fiscal rigour, efficiency and dynamism, while Wallonia incarnates mismanagement and immobilism, N-VA concludes that the Flemish and Walloon governments are incompatible and their forced marriage within the context of federal Belgium is a failure (De Wever 2009a; N-VA 2010; N-VM, 2009a). In particular, the francophone Parti Socialiste (PS, Socialist Party) is systematically portrayed as the main representative of the 'culture of profligacy' within the francophone establishment. In essence, the PS is described as both a usurper and an obstacle to the realisation of the Flemish potential for good governance. This results in a polarising rhetoric, especially emphasised in the 2010 and 2014 elections, of an assumedly unavoidable political choice: 'Flanders chooses more clearly than ever the Nordic-European model, the N-VA model. Wallonia, on the contrary, where people choose the PS model, stands on the edge of a communist breakthrough. Greece is their model' (De Wever in Cobbaert 2014). N-VA's rhetoric also openly draws on the culturally resonant slogan of 'what we do ourselves, we do better' (wat we zelf doen, doen we beter), which was originally launched in the 1980 s by the Flemish government during the first stages of Belgium's federalisation $(\mathrm{N}$ VM 2008c). Furthermore, the party's strategy of communitarisation of governance refers to deep-seated negative stereotypes pitting the independent, productive and hard-working Flemings against the dependent, lazy and profiteering Walloons/francophones (Beland and Lecours 2005: 273-5; Klein et al. 2012: 24-6).

Besides the idea of better governance, since its foundation N-VA has also invoked the notion of democracy to legitimate its demand for independent statehood. Belgium is described as an unworkable 'blocked democracy' since majority rule has been replaced by a mandatory consensus system favouring the francophone minority. The actual federal structure institutionalises the subordination of the Flemings and prevents them from realising their full democratic potential: the francophones turn down any Flemish demand for change (De Wever 2007; De Wever in Het Laatste Nieuws 2008). This rhetoric of minoritisation plays again upon culturally resonant memories of past injustices endured by the Flemings and the 'arrogance' of the French-speaking elite within the so-called 
francophone unitarian Belgian state (Farhat et al. 2014). More fundamentally, N-VA argues that 'Belgium is no longer a democracy' but 'the sum of two democracies' (VM 2005): 'in the 20th century, Belgium gradually split into two different democracies, but its institutions did not sufficiently change along with that evolution' (N-VA 2017a). According to this 'two democracies' argument, Belgium is not a democracy because there are two languages, two cultures, two media systems and two public opinions that cannot be reconciled with each other: 'the separation of the souls has been there for a long time, people only do not dare extend it to the facts' (N-VA 2003: 10; see also De Wever in Het Nieuwsblad 2007: 3; Terzake 2010).

The reference to Belgium as a federation of two incompatible nations actualises the homogenising and essentialist 'we, the people' discourse that characterises both nationalism and populism. On the basis of a supposedly shared identity, N-VA's discourse suggests that the nation is a collective body capable of having a common will and a single interest: 'first and foremost identity is the foundation of our democracy. Identity creates a democratic society that gives substance to citizenship. ... We are Flemish essentially because history has moulded us into a community of destiny of six million people who together on our piece of land form a democracy' (De Wever 2009b). Only Flemish statehood allows a genuine political recognition and democratic expression of the Flemish identity. Although 'the nation' is the central signifier and Flanders vs Wallonia/the francophones constitutes the main antagonism - rather than 'we, the people' vs 'the establishment' - N-VA's rhetoric does show some populist elements. Particularly the representation of the Flemings and Walloons as endowed with a homogenous identity as well as the idea that the majority should rule over the minority, without many checks and balances, testifies to populist leanings.

\section{Economic potential: individual responsibility and welfare producerism}

N-VA's discourse highlights the virtues of the market and opts for limited state intervention: it preaches firm austerity with regard to state spending, a leaner and more efficient government apparatus, more flexible working conditions, lower taxes and labour costs, as well as more market liberalisation (N-VA 2011b). In addition, the party strongly favours a stringent welfare-to-work policy, shifting the focus away from providing unemployed people with income benefits to offering instruments aimed at getting them back to work: the right to work stems from the duty to 
work (N-VA 2014a: 6-8). More generally, access to social benefits should be conditioned by various responsibilities that the citizen must meet.

$\mathrm{N}$-VA clearly tends towards a neoliberal economic view, yet with the qualification that its discourse focuses on the Flemish people of producers and on a reciprocity-based fair redistribution between productive and non-productive citizens. Hence, N-VA's socio-economic worldview, which has become more salient in the party's discourse from the 2009 elections onwards, may be better defined as welfare producerism.

The notion of producerism originates in the study of American populist parties of the early twentieth century (Berlet and Lyons 2000: 6-7; Kindell and Demers 2014: 560-63) and suggests the existence of a virtuous and hardworking middle class that creates the nation's wealth but whose earnings are threatened by the 'non-productive parasites' found both higher and lower in the social order, i.e. the political-economic elite and the undeserving poor. Abts and Kochuyt (2013) adapted the concept to the context of late twentieth century West European welfare states and defined welfare producerism as a conditional concept of solidarity based on the deservingness criteria of control, attitude and reciprocity. Welfare producerism shares with neoliberalism the emphasis on merit and individual responsibility, but focuses on the issue of welfare deservingness. Recipients of social support are generally seen as less deserving if they are deemed to be responsible for their state of need (control) and if they do not make a sufficient effort to get out of their needy situation (attitude), while people who have contributed more to social security are seen as more deserving of help once in need (reciprocity) (compare Jamin 2011; Van Oorschot 2000, 2006). It is important to note that welfare producerism can be complementary to, but is different from, welfare chauvinism (see note 3). This producerist logic fits the neoliberal agenda and also reflects some aspects of conservatism, notably the emphasis on individual responsibility, merit and the conditionality of rights upon duties.

However, we again observe that the nationalist frame communitarises the conflict between welfare producers and recipients. Indeed, within $\mathrm{N}$ VA's discourse welfare producerism comes along with a re-articulation of the left-right cleavage in terms of the distinction between productive and unproductive classes that, in its turn, is explicitly communitarised: the productive Flemish middle class is opposed to the lazy Walloons who parasatise the economic value produced by the former. This representation of the Walloons as undeserving poor living off Flemish labour and sweat enables the party to attract an interclass vote, also because of the strong cultural resonance with the stereotypical image of hard-working Flemings vs. lazy Walloons. References to the billions of euros in taxes and social charges transferred annually from north to south are supposed to 
strengthen the argument. Consequently, N-VA compares Flanders to a 'milk cow' that is undemocratically forced to pay opaque subsidies to Wallonia (N-VA 2003: 16; N-VM 2011c). Speaking of the financial transfers from the north to the south of Belgium as 'a permanent blood transfusion to a patient who parasatise his donor while squeezing his arteries' (De Wever in Ceuppens 2011: 163-4), N-VA suggests the consistent violation of basic rules of reciprocity. The inter-regional transfers presumably create a dangerous culture of too much solidarity nourishing welfare dependency (N-VA 2007: 11; N-VM 2008a; VM 2004). Belgium therefore becomes an obstacle to further Flemish economic development and, more generally, hinders the realisation of Flanders-as-potential: ${ }^{5}$ 'the debts that one makes, still come at the expense of future generations and especially at the expense of the Flemings who pay three-quarters of the bills of this country' (N-VM 2009a). As mentioned above, this socio-economic frame has become more salient since the 2009 election, when the main party slogan was 'Exit Flanders, out of the crisis' (N-VA 2009). In that campaign, N-VA evoked the image of a car (the Flemish nation) running on a highway (Belgium and the crisis) that could get out of its miserable situation by taking the Flanders exit.

In N-VA's cultural-determinist interpretation of regional socio-economic differences, the Flemings are richer because they are more inclined to work, while the Walloons are poorer because they tend to rely on state assistance (N-VM 2009a); the latter attitude is vastly fostered by the Walloon-embedded socialist culture, characterised by economic parasitism and political clientelism (N-VA 2002: 4; 2003: 19). The Belgian institutional structure exacerbates this difference, since the lack of financial responsibility at the regional level enables the PS to keep nurturing Wallonia's welfarist culture without being fully accountable for it (N-VM 2009a). This representation reinforces the argument developed during the interwar years that portrayed Flanders as an internal colony thwarted in its economic development by the francophone establishment (Boehme 2008: 499). Moreover, it resonates with the more recent image of Flanders as an advanced and innovative region needing to invest in its own prosperity to keep up with international competition that was promoted during the 1980s by the Flemish government through the Third Industrial Revolution Programme (Oosterlynck 2009).

\section{Cultural potential: close-knit community and deserved citizenship}

Although individual responsibility is crucial in N-VA's discourse, the nation remains the fundamental locus of meaningful action: it is the symbolic space in which 'we fully participate and we protect our cultural, 
social, economic and environmental achievements' (N-VA 2002: 6). The nation is not merely a collection of free individuals who are only loosely connected by liberal rights and duties, but forms a 'close-knit community' characterised by a 'precious social fabric' (N-VA 2002: 11; see also N-VM 2009b). In this respect, N-VA uses communitarian arguments that portray nationalism as a self-evident phenomenon and a positive force (see also Maly 2013). N-VA indeed presents its nation-building project as based on a civic conception of national identity, carefully distinguishing its 'open and inclusive nationalism' from the 'closed, exclusive and xenophobic' ethnic nationalism propagated by the extreme right, notably Vlaams Belang (De Wever in Renard 2010).

Within the discourse of the traditional Flemish movement, Flemish identity has been systematically contrasted to the Belgian francophones. However, N-VA has not played hard on the linguistic conflict per se (Dalle Mulle 2016: 9-10). Although the party has strongly criticised the francophone parties on specific linguistic issues, particularly regarding the area around Brussels (N-VA 2012), these have not been used as major arguments for more autonomy or independence. Nevertheless, a closer look at N-VA's discourse reveals that cultural elements profoundly permeate it. As we already argued, culture plays a key role in the communitarisation of political and economic themes along the Flanders vs. Wallonia/francophone Belgium opposition. Furthermore, by consistently opposing the Flemish identity to the views and attitudes of the Walloons/francophones, N-VA conveys a quite precise definition of Flemishness entailing a strong work ethic and entrepreneurial attitude, a marked individual responsibility, personal commitment and self-reliance. Through the vast stress on the importance of community and the emphasis on the need for a strong national identity, N-VA's discourse also clearly shows again some affinities with conservatism. Apart from these aspects, however, N-VA has not fully engaged with the moral dimension of Flemish identity and, after the 2010 election, within some policy areas, it has openly defended non-traditionalist views, embracing the liberal-left heritage of the 1960s, such as gender equality and LGBT rights, through their representation as being part and parcel of Flemish culture (N-VM 2012a, 2012b). Furthermore, its claim to be a force for change that opposes the francophone parties defending the status quo can be seen, in part, as contradicting the party's conservatism. However, it is also true that conservatism is compatible with a position favourable to social change if this is carefully managed (see Müller 2006), which seems to be the case of N-VA, as suggested by Bart De Wever's declaration that he believes in 'evolution, not in revolution' (VTM Nieuws 2013). 
The details of N-VA's interpretation of civic nationalism can be seen in the party's position on migration, which is systematically distinguished from, even set against, Belgian-federal immigration policy, this latter being portrayed as reflecting francophone preferences (Adam and Deschouwer 2015: 1291-2). The party advocates an 'active and open integration' policy, yet the current Dutch notion inburgering is more telling since it literally comes down to becoming a citizen through the thorough acquaintance with the predominant Flemish civic culture. This de facto implies a strong assimilation based on Dutch as the common language and supposedly evident values such as free sexual choice and gender equality. In a word, whereas the government has the duty to offer integration trajectories to newcomers, immigrants should become Flemings amongst the Flemings (N-VA 2004: 15; 2009: 34-5; 2011a: 31-2; VM 2001a). N-VA claims that inburgering is not in opposition to the idea or reality of a multicultural society, but only rejects the ideology of multiculturalism (N-VM 2011a): 'N-VA does not ask newcomers to take off their identity at the border or to relinquish their faith. We rather ask to share our public culture, to learn our language, and to respect and comply with the basic rules of our society' (N-VA 2017b). In this sense, 'citizenship has all to do with your willingness to belong to the community' (Bourgeois 2007). As a result, integration is not just a choice but a requirement, since N-VA considers the granting of both Belgian nationality and local voting rights as depending on the successful completion of an 'integration trajectory' (N-VA 2002: 7). Thus, the party's self-proclaimed inclusive nationalism is rather selective and conditional: it assumes the notion of earned citizenship (Andreouli and Stockdale 2009; Van Houdt et al. 2011). Moreover, N-VA's programme has not been free of nativist accents. For instance, in 2007, it foresaw a community preference principle according to which employers should first recruit EU candidates to the detriment of non-EU workers (N-VA 2007: 30).

N-VA strongly opposes illegal immigration (N-VA 2009: 90-91) and, more generally, portrays migration as a phenomenon that must be carefully managed. Only a limited number of well-screened newcomers should be allowed, which logically requires quotas and the repatriation of illegal migrants (N-VA 2007: 26-30; 2009: 90-91; VM 2001a). This stance has become more explicit in conjunction with the 2015-2016 refugee crisis and resulted in fierce criticism of several policy decisions taken by the Belgian federal government in the recent past. N-VA strongly opposed the so-called snel-Belg wet (which eased the acquisition of Belgian nationality), the 2009 collective regularisation of certain categories of illegal migrants, and the supposedly 'lax way' in which the government dealt with family reunification. Through its opposition to Belgian federal 
migration policy and its defence of Flemish integration policy in terms of inburgering, N-VA once again openly communitarises this topic: 'also in these matters, the communitarian conflict is deep-seated. ... Whereas Flanders offers chances to newcomers, but also formulates requirements, the federal level gives the Belgian nationality generously away without any demands' (N-VM 2008b). In effect, since their domination of border control policy at the federal level allows 'uncontrolled migration', the francophones still threaten the full realisation of the Flemish nation and its cultural identity. Hence, Belgium hinders the realisation of Flanders' cultural potential since it stands in the way of 'a good welcome policy that makes cultural and socio-economic integration possible' (N-VA 2009: 35$)^{6}$

\section{N-VA's socio-political space: homological and antagonistic relations}

Through the consistent communitarisation of various issues, N-VA's discourse repeatedly emphasises that the Flemish nation is hindered in the realisation of its full potential: Flanders cannot achieve good governance and exercise its legitimate democratic power, take complete advantage of its economic prosperity, welfare and culture of industriousness, and stick to its own values and manage cultural diversity in a way conducive to the preservation of a 'close-knit community'. Yet how does this purported obstruction occur in practice according to N-VA? Who are the main actors in the Belgian drama discursively staged by N-VA and how do they relate to each other? In order to answer this question, we move the focus from the level of issues to be dealt with to that of agency, from that of diagnosis and prognosis to that of blame attribution and credit taking. In other words, we examine how the party discursively structures the socio-political space.

Overall, our analysis demonstrates that N-VA's representation of this space hinges on the opposition of two homological relationships between four basic terms: the Flemish nation; N-VA as the embodiment of the Flemish identity and general will; the political or superordinate Other; and the social or subordinate Other (Figure 1). The first homological relationship is that between Flanders and N-VA, which forms the Flemish axis (= the horizontal axis in Figure 1); the second is that between the political (or superordinate) Other and the social (or subordinate) Other, which forms the anti-Flemish axis (= the vertical axis in Figure 1). While the ends of the Flemish axis are stable, those of the anti-Flemish one change depending on whether the party is dealing with the federal or regional arena. 
Francophone Establishment / Flemish ‘Belgicist' Establishment

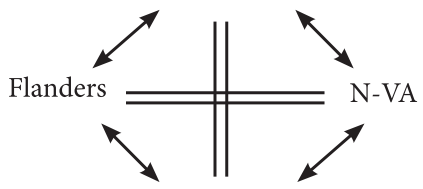

Walloon Profiteers / (Unclear)

Figure 1. N-VA's discursive diamond in the federal and regional arenas.

At the federal level, the francophone political elite is positioned as the overt adversary since it opposes any Flemish demand for more autonomy or institutional change and de facto overrules the will of the Flemish majority. The argument is that Flanders is not ruled by its own leaders but by anachronistic francophone parties - especially the leftist PS - that are only interested in maintaining the status quo and the financial transfers from Flanders to Wallonia and Brussels (De Wever 2006; De Wever in Killemaes and Van Overtveldt 2011; N-VM 2007). In sharp contradistinction, and especially since $2014, \mathrm{~N}-\mathrm{VA}$ positions itself as a future-oriented force, as the 2014 campaign slogan 'Change for Progress' (Verandering voor Vooruitgang) clearly illustrates. At the regional level, the Flemish 'Belgicist' parties are accused of betraying the Flemish people (Bourgeois 2003; N-VA 2007: 5; N-VM 2010). They collaborate with the francophone establishment in exchange for political power and in this way 'mortgage the future of six million Flemings' (N-VM 2009a). Instead of demanding a further empowerment of the regions, they rather stick to the 'festering Belgian compromise' and continue to look for half-hearted solutions, thus contributing to the maintenance of the status quo (N-VA 2014b: 2). ${ }^{7}$

Besides targeting the political establishment as a superordinate Other, $\mathrm{N}-\mathrm{VA}$ also refers in its nationalist dramaturgy to a subordinate social Other embodying a threat from below to Flemish identity and welfare. At the federal level, this Other is mainly identified with the lazy Walloons enjoying the 'hammock' of social security to the detriment of Flemish finances (N-VM 2011b; VM 2005). In this connection, the party's discourse alternates between more stigmatising utterances (see De Wever in Schlamp and Schult 2010) and collaborative statements portraying francophone political parties - particularly the PS - as responsible for Wallonia's welfare dependency. At the Flemish level, the subordinate social Other is less clearly defined. Nevertheless, N-VA sometimes negatively invokes in this regard 'progressive-intellectual Flanders', made up of the Flemings who oppose a new reform of the federal state, who are not convinced of the party's nation-building project, and who supposedly align themselves with the old francophone elites who want to maintain 
the Belgian status quo (De Wever 2005). The main features of this Other are rarely explicitly conveyed and are more a matter of connotation than denotation - of a latent set of representations that parasitises the more explicit nationalist rhetoric articulated at the federal level. This discursive vagueness may be due to the fact that clearly identifying an Other from below within Flanders would have inevitable divisive effects that could be electorally counterproductive, while externalising stigmatisation through the previously analysed strategy of communitarisation offers the potential for articulating an electoral coalition consisting of different social subgroups that complements the nationalist core electorate (Abts and Swyngedouw 2014).

The discursive homology between the preservation of the status quo and the francophone/Flemish establishment suggests that those who want change have to vote for N-VA. Building on a lingering resentment linked to historical narratives of Flemish victimisation (Art 2008: 427; Farhat et al. 2014: 396) in a Belgium led by a francophone elite, N-VA describes itself both as an injured victim of the arrogant francophones and as the real force of change that will give the Flemish nation its own voice. ${ }^{8}$ Particularly the party's self-presentation has capitalised on the distinction between realism and naïveté, on the one hand, and purity and contamination, on the other, with the party obviously claiming to embody realism and purity. N-VA presents itself as the only political force that dares to face the facts, speaks the truth and wants to solve the real issues ignored or concealed by the other parties (Bourgeois 2001; N-VM 2011d). The party's leader, Bart De Wever, especially masters the discursive genre of new realism (see Prins 2002) by portraying N-VA's solutions to so-called indisputably objective problems in Flemish society as inevitable. The Alliance thus positions itself as the neutral emanation of Flemish common sense (most recently conveyed through the image of grondstroom, or literally 'ground current') and the authentic voice of 6 million Flemings (N-VM 2014): it is a party 'of and for principled people who do what they say, who keep their word' (N-VA 2001). These and related statements are in line with the populist logic of unmediated embodiment. Although its electoral strength equals about a third of the Flemish vote, the party talks as if it represented the whole of the Flemish people (compare Maly 2012: 214). Also, by placing Flanders in opposition to 'socialist Wallonia' and the 'PS-model', N-VA implicitly suggests that Flanders is more right-wing and that progressive parties stand in the way of the plebiscitary will of their region (VM 2001a). Once again, this representation plays on a culturally resonant narrative of Flanders as more Catholic and conservative than liberal Brussels and socialist Wallonia (see De Smaele 2009). 


\section{Conclusion}

In this article, we have analysed the multi-dimensional ideological discourse that underlies N-VA's strategy of vote maximisation through issue diversification and its concomitant appeal to different electoral subgroups. ${ }^{9}$ Within academic literature, N-VA has generally been described as a nationalist, populist, neoliberal and conservative party. Our in-depth analysis of N-VA's discourse confirms the relevance of these labels, yet also nuances them and adds new conceptual constructs. In particular, we conclude that the party's Flemish nationalism subsumes the ideological frames of neoliberalism, populism and conservatism through a strategy of issue communitarisation that systematically represents different types of social conflicts as expressions of the all-encompassing and unresolvable antagonism between the Flemish and francophone communities within the context of federal Belgium. Furthermore, N-VA's discourse structures the socio-political space around the opposition between two homological axes: the Flemish axis consisting of Flanders and N-VA, and the antiFlemish axis composed of a superordinate political and a subordinate social Other. In line with the logic of issue communitarisation, this twofold structure is over-determined by the party's nationalist ethos: the specifications of the superordinate and subordinate Others at the regional Flemish level are to a great extent derivations of the much clearer Others identified at the federal Belgian level, which is N-VA's prime target since the party aims at Flemish political autonomy.

In a comparative perspective, the discursive strategy of issue communitarisation contributes to understanding how SNRPs can diversify their policy portfolio while at the same time keeping the support of committed hardcore nationalists. Instead of simply going beyond centre-periphery, N-VA has 'exported' the centre-periphery frame to other ideological conflicts, thus addressing the paradox, suggested by Alonso, whereby 'the more the party wins at the centre the more it loses at the extreme' (Alonso 2012: 221).

This strategy is also interesting in a diachronic comparative perspective. As shown by Deschouwer (2009) and Van Haute and Pilet (2006), having not sufficiently diversified their policy proposals after devolution, Belgian regionalist parties (among which the VU) quickly became 'victims of their own success'. In later articles, Beyens et al. (2017: 4-5) and Wauters and Bouteca (2016) have concluded that N-VA has become markedly differentiated from its predecessor throughout the 2000s, especially on left-right issues, thus confirming that an effective strategy of issue diversification did go along with N-VA's success. More specifically, 'as regionalist parties were pluralist parties on socio-economic and on ideological issues, tensions emerged when they had to define themselves on issues other than the "pure" regionalist issue' (Van Haute and Pilet 
2006: 309). Such lack of consensus led to the VU's split. As a more homogenous party, N-VA could complete the issue diversification process by setting up a clearly centre-right profile characterised by neoliberal, populist, conservative and welfare producerist undertones and in which nationalism constitutes the glue that holds together these different frames. Hence, the N-VA-VU comparison reveals that SNRPs cannot only be victims of their own success, but also of their internal divisions, since a modicum of consensus on issues related to the transformed socio-economic and cultural cleavages is required in order for them to diversify successfully and communitarise their agenda.

Finally, in a wider theoretical perspective, N-VA's strategy of communitarisation may be related to already formulated theoretical insights about the nature of nationalism as a specific ideology. Michael Freeden (1998) in particular has denied nationalism's status as a fully fledged ideology and argued that it is a thin conceptual construct attaching itself to more complex ideological systems. While our analysis confirms this flimsy nature of nationalism, it also suggests that a nationalist stance may actively articulate other conceptual frameworks rather than being subsumed within them. In other words, nationalism seems rather to act as a flexible shell - to paraphrase Laclau and Mouffe's (1986) analysis of ideological hegemony in terms of one or more hollowed out master signifiers - that can accommodate other ideologies and frames. This is because nationalism focuses on the determination of the relevant sovereign community and its political legitimacy, which is logically prior to the application of principles making up other ideologies that provide 'plans of actions for public political institutions'. As a result, nationalist discourse can embed more complex ideologies in a particular social and territorial context, contribute to the determination of a collective interest, endow the political and economic spheres with a particular moral and emotional nature, and define the boundaries of solidarity.

\section{Notes}

1. Lynch (2009) has argued that the party later moved back to a 'no ideology' position, but this has been in part nuanced by recent research on party membership showing that the party is clearly perceived as being firmly in the centre-left (Mitchel et al. 2011: 125-6).

2. Although certainly interesting, properly accounting for the post-2014 election period would require too long a treatment and therefore it would not fit within the limits of this paper.

3. Welfare producerism is different from welfare chauvinism in that welfare chauvinism refers to the ascribed criterion of identity, while, as we will explain in more detail below, producerism refers to the behavioural criteria of control, attitude and reciprocity. 
4. Although the terms 'Walloon' and 'francophone' are often used as synonyms in the party's propaganda, the former is most frequently adopted with regard to economic issues, whereas the latter most often relates to cultural and political issues.

5. 'Flanders-as-potential' is not an expression found in N-VA's discourse. With this formula, which hints at the more general actual vs. potential distinction, we intend to summarise the representation of Flanders as a community hindered in the realisation of its full political, economic and cultural possibilities.

6. This refers to the period before N-VA joined the 2014 federal government coalition, in which it became responsible for migration policy.

7. In fact, N-VA has continuously been in government with other Flemish parties at the regional level since 2004 and simultaneously criticised its governmental partners for their actions at the federal level.

8. As mentioned before, this is superficially in contradiction with the conservative profile of the party. However, as pointed out by Müller (2006), the defence of a process of carefully managed change can be in line with conservative thinking.

9. What we could not do, for reasons of scope (see note 2), was to venture into the most recent period, after the 2014 elections, when the N-VA took the unprecedented decision to join a federal government coalition, or extensively to compare the party with its immediate predecessor, i.e. the VU. However, both may well be topics for future research.

\section{Acknowledgements}

Emmanuel Dalle Mulle would like to thank the Swiss National Science Foundation for its financial support (grant P2GEP1_165085) and the Institute for Social and Political Opinion Research at the University of Leuven for hosting him during the preparation of this paper.

\section{Disclosure statement}

No potential conflict of interest was reported by the authors.

\section{Notes on contributors}

Koen Abts is Assistant Professor at Tilburg University and Research Fellow at the Institute of Social and Political Opinion Research, University of Leuven. His research interests include resentment, welfare attitudes, radical right parties, voting behaviour and Belgian politics. [k.abts@uvt.nl]

Emmanuel Dalle Mulle is a Post-doctoral Researcher at the Graduate Institute of International and Development Studies, Geneva, and non-resident Fellow at the Centre for Sociological Research, University of Leuven. His interests include Western European nationalist parties, welfare nationalism, minority-majority relations and separatism. [emmanuel.dallemulle@graduateintitute.ch]

Rudi Laermans is Professor of Social Theory at the University of Leuven. His research and publications are situated within the fields of social theory, cultural 
sociology and the sociology of the arts, especially the performing arts. [rudi.laermans@kuleuven.be]

\section{ORCID}

Koen Abts iD http://orcid.org/0000-0001-8546-8347

Emmanuel Dalle Mulle (D) http://orcid.org/0000-0002-9260-5925

\section{References}

Abts, Koen and Thierry Kochuyt (2013). 'De vreemde bedreiging van de verzorgingstaat', Tijdschrift voor Sociologie, 34:3-4, 227-49.

Abts, Koen and Stefan Rummens (2007). 'Populism versus Democracy', Political Studies, 55:2, 405-24.

Abts, Koen and Marc Swyngedouw (2014). 'Het profiel van het N-VA electoraat in 2010', in Koen Abts, Marc Swyngedouw, Jaak Billiet and Bart Meuleman (eds.), Vlaanderen Kiest. Tielt: Lannoo Campus, 192-217.

Abts, Koen and Rudi Laermans (2018). 'Populism: Definitions, Questions, Problems, and Theories', in Günther Pallaver, Michael Gehler and Maurizio Cau (eds.), Populism, Populists, and the Crisis of Political Parties: A Comparison of Italy, Austria, and Germany 1950-2015. Bologna/Berlin: Il Mulino/ Duncker\&Humblot, 63-80.

Adam, Ilke and Kris Deschouwer (2015). 'Nationalist Parties and Immigration in Flanders: From Volksunie to Spirit and N-VA', Journal of Ethnic and Migration Studies, 42:8, 1290-1303.

Albertazzi, Daniele and Duncan McDonnell (2008). 'Introduction: The Sceptre and the Spectre', in Daniele Albertazzi and Duncan McDonnell (eds.), TwentyFirst Century Populism: The Spectre of Western European Democracy. Basingstoke: Palgrave Macmillan.

Alonso, Sonia (2012). Challenging the State: Devolution and the Battle for Partisan Credibility. Oxford: Oxford University Press.

Anderson, Benedict (1983). Imagined Communities: Reflections on the Origins and Spread of Nationalism. London: Verso.

Andreouli, Eleni and Jan E. Stockdale (2009). 'Earned Citizenship: Assumptions and Implications'. Tottel's Journal of Immigration Asylum and Nationality Law, 23:2, $165-80$.

Art, David (2008). 'The Organizational Origins of the Contemporary Radical Right: The Case of Belgium', Comparative Politics, 40:4, 421-40.

Beland, Daniel and André Lecours (2005). 'Nationalism, Public Policy, and Institutional Development: Social Security in Belgium', Journal of Public Policy, 25:2, 265-85.

Berlet, Chip and Matthew Lyons (2000). Right-Wing Populism in America: Too Close to Comfort. New York: The Guilford Press.

Bell, Daniel (1973). The Coming of Post-Industrial Society: A Venture in Social Forecasting. New York: Basic Books.

Beyens, Stefanie, Kris Deschouwer, Emilie van Haute and Tom Verthé (2017). 'Born Again, Born Anew? Assessing the Newness of the Belgian Political Party New-Flemish Alliance (N-VA)', Party Politics, 23:4, 389-99.

Boehme, Olivier. (2008). Greep naar de markt. Tielt: Lanoo. 
Brown, Wendy (2006). 'American Nightmare. Neoliberalism, Neoconservatism, and De-Democratization', Political Theory, 34:6, 690-714.

Brubaker, Rogers (2004). Ethnicity without Groups. Cambridge, MA: Harvard University Press.

Calhoun, Craig (1997). Nationalism. Minneapolis: University of Minnesota Press.

Canovan, Margaret (2002) 'The People, the Masses, and the Mobilization of Power: The Paradox of Hannah Arendt's "Populism", Social Research, 69:2, 403-22.

Ceuppens, Bambi (2011). "From "the Europe of the Regions" to "the European Champion League": The Electoral Appeal of Populist Autochthony Discourses in Flanders', Social Anthropology, 19:2, 159-74.

Culla i Clara, Joan (2013). Esquerra Republicana de Catalunya 1931-2012: una història politica. Barcelona: La Campana.

Dalle Mulle, Emmanuel (2016). 'New Trends in Justifications for National SelfDetermination: Evidence from Scotland and Flanders', Ethnopolitics, 15:2, 211-29.

Dalle Mulle, Emmanuel (2018). The Nationalism of the Rich: Discourses and Strategies of Separatist Parties in Catalonia, Flanders, Northern Italy and Scotland. London: Routledge.

Dalle Mulle, Emmanuel and Serrano, Ivan (2018). 'Between a Principled and a Consequentialist Logic: Theory and Practice of Secession in Catalonia and Scotland', Nations and Nationalism, https://doi.org/10.1111/nana.12412

Dandoy, Régis (2010). 'Ethno-Regionalist Parties in Europe: A Typology', Perspectives on federalism, 2:2, 194-220.

Deschouwer, Kris (2009). 'The Rise and Fall of the Belgian Regionalist Parties', Regional and Federal Studies, 19:4-5, 559-77.

De Smaele, Henk (2009). Rechts Vlaanderen. Religie en stemgedrag in negentiendeeeuws Belgie. Leuven: Leuven University Press.

Elias, Anwen and Tronconi, Filippo (2011). 'Introduction: Autonomist Parties and the Challenges of Political Representation', in Anwen Elias and Filippo Tronconi (eds.), From Protest to Power: Autonomist Parties and the Challenges of Representation. Vienna: Braumüller, 1-25.

Farhat, Nadim, Valérie Rosoux and Philippe Poirier (2014). 'The Causal Pattern of Collective Memory in a Community Conflict: "Constant Causes" in the Belgium Case', Nationalism and Ethnic Politics, 20:4, 393-414.

Foucault, Michel (2008). The Birth of Biopolitics. Basingstoke: Palgrave Macmillan.

Freeden, Michael (1996). Ideologies and Political Theory: A Conceptual Approach. Oxford: Oxford University Press.

Freeden, Michael (1998). 'Is Nationalism a Distinct Ideology?', Political Studies, 46:4, 748-65.

Gellner, Ernest (1983). Nations and Nationalism. Ithaca: Cornell University Press.

Greenfeld, Liah (1992). Nationalism: Five Roads to Modernity. Cambridge, MA: Harvard University Press.

Habermas, Jürgen (1984). The Theory of Communicative Action. Boston: Beacon Press.

Hall, Stuart (1986). 'The Problem of Ideology: Marxism Without Guarantees', Journal of Communication Inquiry, 10:2, 28-44.

Hall, Stuart (1988). The Hard Road to Renewal: Thatcherism and the Crisis of the Left. London: Verso.

Hall, Peter A. and Michèle Lamont (eds.) (2013). Social Resilience in the Neoliberal Era. Cambridge: Cambridge University Press. 
Harvey, David (2005). A Brief History of Neoliberalism. Oxford: Oxford University Press.

Huntington, Samuel (1957). 'Conservatism as an Ideology', American Political Science Review, 51:2, 454-73.

Jamin, Jerome (2011). 'The Producerist Narrative in Right-Wing Flanders', in Bruno De Wever (ed.), Right-Wing Flanders, Left-Wing Wallonia? Is this so? If so, why? And is it a Problem? Brussels, Belgium: Re-Bel e-book 12, 25-35.

Kindell, Alexandra and Elizabeth S. Demers (2014). Encyclopedia of Populism in America: A Historical Encyclopedia. Santa Barbara: ABC-CLIO.

Klein, Olivier, Laurent Licata, Nicolas Van der Linden, Aurélie Mercy and Olivier Lumine (2012) 'A Waffle-Shaped Model for How Realistic Dimensions of the Belgian Conflict Structure Collective Memories and Stereotypes', Memory Studies, 5:1, 16-31.

Laclau, Ernesto and Chantal Mouffe (1986). Hegemony and Socialist Strategy: Towards a Radical Democratic Politics. London: Verso.

Larner, Wendy (2000). 'Neoliberalism: Policy, Ideology, Governamentality', Studies in Political Economy, 63:1, 5-25.

Lynch, Peter (2002). SNP: The History of the Scottish National Party. Cardiff: Welsh Academic Press.

Lynch, Peter (2009). 'From Social Democracy back to No Ideology? - The Scottish National Party and Ideological Change in a Multi-level Electoral Setting, Regional \& Federal Studies, 19:4-5, 619-637.

Maly, Ico (2012). N-VA. Analyse van een politieke ideologie. Berchem: EPO.

Maly, Ico (2013). "Scientific Nationalism". N-VA, Banal Nationalism and the Battle for Flemish Nationalism', Tilburg Papers in Culture Studies 63.

Maly, Ico and Jan Zienkowski (eds.) (2011). Het Rijpen van de Geesten. Antwerpen: Kif Kif.

Mény, Yves and Yves Surel (2002). 'The Constitutive Ambiguity of Populism', in Yves Mény and Yves Surel (eds.), Democracies and the Populist Challenge. Basingstoke: Palgrave Macmillan, 1-21.

Mitchell, James (1988). 'Recent Developments in the Scottish National Party', Political Quarterly, 59:4, 473-477.

Mitchell, James, Lynn Bennie and Rob Johns (2011). The Scottish National Party: Transition to Power. Oxford: Oxford University Press.

Mudde, Cas (2000). The Ideology of the Extreme Right. Manchester: Manchester University Press.

Mudde, Cas (2004) 'The Populist Zeitgeist', Government \& Opposition, 39:4, 542-63.

Mudde, Cas and Cristobal Rovira Kaltwasser (2017). Populism: A Very Short Introduction. Oxford: Oxford University Press.

Müller, Jan-Werner (2006). 'Comprehending Conservatism: A New Framework for Analysis'. Journal of Political Ideologies, 11:3, 359-65.

Noppe, Jo and Bram Wauters (2002). 'Het uiteenvallen van de Volksunie en het ontstaan van de N-VA en Spirit: een chronologisch en morfologisch overzicht', Res Publica: Tijdschrift voor Politologie, 2:3, 397-471.

Oakeshott, Michael (1991). 'On Being Conservative', in Michael Oakeshott (ed.), Rationalism in Politics. Indianapolis: Liberty Fund, 407-437.

Oosterlynck, Stijn (2009). 'The Political Economy of State Restructuring and the Regional Uneven Transition to After-Fordism in Belgium', in Michel 
Huysseune (ed.), Contemporary Centrifugal Regionalism: Comparing Flanders and Northern Italy. Brussels: KVABWK, 83-94.

Pauwels, Teun (2011). 'Measuring Populism: A Quantitative Text Analysis of Party Literature in Belgium', Journal of Elections, Public Opinion and Parties, 21:1, 97-119.

Peck, Jamie and Adam Tickell (2002). 'Neoliberalizing Space', Antipode, 34:3. 380-404.

Prins, Baukje (2002). 'The Nerve to Break Taboos: New Realism in the Dutch Discourse on Multiculturalism', Journal of International Migration and Integration, 3:3, 363-79.

Rochtus, Dirk (2012). 'The Rebirth of Flemish Nationalism: Assessing the Impact of N-VA Chairman Bart De Wever's Charisma', Studies in Ethnicity and Nationalism, 12:2, 268-85.

Sainsbury, Diane (1980). Swedish Social Democratic Ideology and Electoral Politics 1944-1948. A Study of the Functions of Party Ideology. Stockholm: Almqvist \& Wicksell.

Smith, Anthony (1999). Myth and Memories of the Nation. Oxford: Oxford University Press.

Stavrakakis, Yannis (2004). 'Antinomies of Formalism: Laclau's Theory of Populism and the Lessons from Religious Populism in Greece', Journal of Political Ideologies, 9:3, 253-67.

Swyngedouw, Marc, Koen Abts, Sharon Baute, Jolien Galle and Bart Meuleman (2015). Het Communautaire in de Verkiezingen van $25 \mathrm{Mei}$ 2014. Analyse op basis van de postelectorale Verkiezingonderzoeken 1991-2014. Leuven: ISPO.

Triandafyllidou, Anna (1998). 'National Identity and the "Other"', Ethnic and Racial Studies, 21:4, 593-612.

Van Haute, Emilie and Jean-Benoit Pilet (2006). 'Regionalist Parties in Belgium (VU, RW, FDF): Victims of their Own Success?', Regional and Federal Studies, 16:3, 297-313.

Van Houdt, Friso, Semin Suvaveriol and Willem Schinkel (2011). 'Neoliberal Communitarian Citizenship: Current Trends towards "Earned Citizenship" in the United Kingdom, France and the Netherlands', International Sociology, 26: 3, 408-32.

Van Oorschot, Wim (2000). 'Who Should Get What, and Why?', Policy and Politics, 28:1, 33-49.

Van Oorschot, Wim (2006). 'Making the Difference in Social Europe', Journal of European Social Policy, 16:1, 23-42.

Wauters, Bram (2005). 'Divisions within an Ethno-regional Party: The Volksunie in Belgium'. Regional and Federal Studies, 15:3, 329-52.

Wauters, Bram and Nicolas Bouteca (2016) 'Van Volksunie (VU) naar NieuwVlaamse Alliantie (N-VA). Een analyse van de ideologische opvattingen van hun partijleden', Res Publica, 58:3, 317-340.

Zizek, Slavoj (1994) 'Introduction: The Spectre of Ideology', in Slavoj Zizek (ed.), Mapping Ideology. London: New Left Books.

\section{Primary sources}

Bourgeois, Geert (2001). 'Slottoespraak'. Speech to N-VA's first national meeting. Ghent, 5 December. 
Bourgeois, Geert (2003). 'Slottoespraak'. Speech to N-VA's electoral meeting, 4 May.

Bourgeois, Geert (2007). 'Zonder identiteit is er geen toekomst', De Morgen, 6 September, 99.

Cobbaert, Paul (2014). “Wij gaan voor een besparingslogica”, De Zondag, 27 April, 12-13.

De Wever, Bart (2005). 'Het kostbare weefsel', De Standaard, 14 February, 47.

De Wever, Bart (2006). 'Bouwstenen voor een lokaal beleid: slottoespraak'. Speech to N-VA's second national congress, 11 February.

De Wever, Bart (2007). '2007 was een kanteljaar', De Morgen, 24 December, 15.

De Wever, Bart (2009a). 'Nieuwjaarstoespraak'. Speech to N-VA's New Year reception, 1 February.

De Wever, Bart (2009b). 'Een lotsgemeenschap op een culturele sokkel', De Morgen, 20 November, 28.

Het Laatste Nieuws (2008). 'De Wever: "Dictatuur van minderheid moest stoppen", 15 July, available at http://www.hln.be/hln/nl/957/Belgie/article/ detail/348127/2008/07/15/De-Wever-Dictatuur-van-minderheid-moest-stoppen-. dhtml (accessed 25 August 2017).

Het Nieuwsblad (2007). 'Franstalige onwil', 24 September, 3.

Killemaes, Daan and Johan Van Overtveldt (2011). 'Bart De Wever. "15 miljard besparen kan zonder sociaal bloedbad", Trends, 29 June, available at http:// trends.knack.be/economie/beleid/bart-de-wever-15-miljard-besparen-kan-zondersociaal-bloedbad/article-normal-233121.html (accessed 25 August 2017).

Knack (2010). 'De Wever in Der Spiegel: België is zieke man van Europa', 13 December, available at http://www.knack.be/nieuws/belgie/de-wever-in-derspiegel-belgie-is-zieke-man-van-europa/article-normal-12067.html (accessed 25 August 2017).

N-VA (2001). 'Beginselverklaring'. Declaration of principles, 13 October.

N-VA (2002). 'De Nieuw-Vlaamse Alliantie in vraag en antwoord - Deel I'. September.

N-VA (2003). 'Waarom N-VA? 18 redenen voor zes miljoen Vlamingen'. Federal election manifesto.

N-VA (2004). 'Voorstellen voor het Vlaanderen van de 21ste eeuw'. Regional election manifesto.

N-VA (2007). 'Voor en sterker Vlaanderen'. Federal election manifesto.

N-VA (2009). 'Afrit Vlaanderen, uitrit crisis'. Regional and European election manifesto.

N-VA (2010). 'Nu durven veranderen. En sterk sociaal en economisch perspectief voor Vlaanderen en Wallonië'. Federal election manifesto.

N-VA (2011a). 'Migratie, een uitdaging: de totaalvisie van de N-VA'. Electoral brochure.

N-VA (2011b). 'N-VA betreurt staking en ijvert voor minimale dienstverlening bij De Lijn'. Press release, available at https://www.n-va.be/persbericht/n-vabetreurt-staking-en-ijvert-voor-minimale-dienstverlening-bij-de-lijn (accessed 25 August 2017).

N-VA (2012). 'BHV Splitst à la Belge. Franstaligen de lusten, Vlamingen de lasten'. Electoral brochure.

N-VA (2014a). 'Verandering voor Vooruitgang'. Federal, regional and European election manifesto. 
N-VA (2014b). 'Verandering voor Vooruitgang'. Congress brochure, 31 January-2 February.

N-VA (2017a). 'Is the N-VA a nationalist party?', available at https://english.n-va. be/frequently-asked-questions (accessed 25 August 2017).

N-VA (2017b). 'Inburgering', available at https://www.n-va.be/standpunten/inburgering (accessed 25 August 2017).

N-VM (Nieuw-Vlaams Magazine) (2007). September: p. 3.

N-VM (2008a). February: p. 11.

N-VM (2008b). Juni: p. 10.

N-VM (2008c). October: p. 8.

N-VM (2009a). October: p. 3.

N-VM (2009b). December: pp. 4-7.

N-VM (2010). February: p. 9.

N-VM (2011a). March: p. 8.

N-VM (2011b). November: p. 3.

N-VM (2011c). December: pp. 6-8.

N-VM (2011d). June: p. 3.

N-VM (2012a). March: p. 12.

N-VM (2012b). May: p. 2.

N-VM (2014). June: pp. 4-5.

Renard, H. (2010). 'EVA komt goed van pas', Knack, 7 April, 32.

Schlamp, Hans-Jürgen and Christoph Schult (2010). 'Belgie: Europas kranker Mann', Der Spiegel, 13 December.

Terzake (2010). 'België: twee democratieën in één land?', 15 June, available at http://deredactie.be/permalink/1.802137 (accessed 25 August 2017).

VM (Volle Manen) (2001a). November: pp. 9-15.

VM (2004). May: p. 3.

VM (2005). July: pp. 8-9.

VTM Nieuws (2013) 'Geloven in evolutie, niet in revolutie', 18 March, https:// nieuws.vtm.be/binnenland/41006-geloven-evolutie-niet-revolutie (accessed on May 11, 2018. 